\title{
Infratentorial Cistern
}

National Cancer Institute

\section{Source}

National Cancer Institute. Infratentorial Cistern. NCI Thesaurus. Code C32798.

Any of the following subarachnoid cisterns: anterior, lateral, posterior and superior infratentorial cistern. 